\title{
BALANITES MAUGHAMII SPRAGUE (ZYGOPHYLLACEAE) IN TROPICAL AFRICA: A SYNTHESIS AND REVIEW OF ITS CHEMISTRY, PHARMACOLOGY, AND MEDICINAL POTENTIAL
}

\author{
ALFRED MAROYI \\ Department of Botany, Medicinal Plants and Economic Development Research Centre, University of Fort Hare, Private Bag X1314, \\ Alice 5700, South Africa. Email: amaroyi@ufh.ac.za
}

Received: 03 May 2019, Revised and Accepted: 04 June 2019

\begin{abstract}
Balanites maughamii is an important medicinal plant species in Southern Africa. This study is aimed at providing a critical review of the biological activities, phytochemistry, and medicinal uses of $B$. maughamii. Documented information on biological activities, medicinal uses, and phytochemistry of B. maughamii was collected from several online sources which included BMC, Scopus, SciFinder, Google Scholar, Science Direct, Elsevier, PubMed, and Web of Science. Additional information on the biological activities, phytochemistry and medicinal uses of B. maughamii were collected from preelectronic sources such as book chapters, books, journal articles, theses, and scientific publications sourced from the university library. This study showed that the bark, fruits, leaves, and roots of B. maughamii are traditionally used for magical purposes, as emetic, tonic, fish poison, insecticidal, and herbal medicine for bilharzia. Phytochemical compounds identified from the bark, fruits, and leaves of B. maughamii are aliphatic alcohols, aliphatic ketones, benzenoid compounds, aliphatic acids, amino acids, coumarin, aliphatic esters, flavonoids, aliphatic aldehydes, and sterol. Pharmacological research revealed that $B$. maughamii extracts have adulticidal, antibacterial, antiplasmodial, bitterness, molluscicidal, and mutagenic activities. Future research should focus on evaluating the phytochemical, pharmacological, and toxicological properties of $B$. maughamii crude extracts as well as compounds isolated from the species.
\end{abstract}

Keywords: Balanites maughamii, Ethnopharmacology, Herbal medicine, Indigenous pharmacopeia, Southern Africa, Zygophyllaceae.

(C) 2019 The Authors. Published by Innovare Academic Sciences Pvt Ltd. This is an open access article under the CC BY license (http://creativecommons. org/licenses/by/4. 0/) DOI: http://dx.doi.org/10.22159/ajpcr.2019.v12i7.33915

\section{INTRODUCTION}

Balanites maughamii Sprague is a member of the Zygophyllaceae family. The Zygophyllaceae family is a heterogeneous family consisting of about 23 genera and 235 to 240 species in the dry regions of Africa, America, Australia, Asia, and Europe [1]. Delimitation of taxa within the Zygophyllaceae family has repeatedly changed over time. For example, the genus Balanites Delile has been assigned its own family Balanitaceae due to unique morphological and anatomical characteristics [2-4]. However, other researchers, for example, Cronquist [5], Fahn et al. [6], and Narayana et al. [7] included the genus Balanites in Zygophyllaceae family. Evaluation of phylogenetic relationships within the Zygophyllaceae family based on DNA sequences of non-coding trnL-F and plastid gene rbcL region support assignment of the genus Balanites in the Zygophyllaceae family [1,8-11]. The genus name "Balanites" was derived from a Greek word which means "acornshaped" in reference to the fruits of the genus $[12,13]$. The species name "maughamii" is in honor of Mr. Maugham, the former British Consul at Lourenco Marques (now Maputo in Mozambique) who collected the type specimen of the species in Southern Mozambique [13-16]. The synonym of B. maughamii is B. dawei Sprague [17]. The English common names of the species "torchwood," "torch fruit tree," and "y-thorned torchwood" are in reference to the dry kernels of the species which have traditionally been burnt as torches [13,14,16-19]. B. maughamii is one of the valuable medicinal plant species in South Africa, and the species is included in the book "medicinal plants of South Africa," a photographic guide to the most commonly used herbal medicines in the country, including its botany, major medicinal applications active phytochemical compounds [20]. According to Van Wyk and Gericke [21] and Van Wyk et al. [20], B. maughamii is considered an important tonic in Southern Africa. Due to the popularity of B. maughamii as traditional medicine, the bark of the species is marketed as a traditional medicine in the traditional medicine informal markets in Gauteng, KwaZulu-Natal, and Mpumalanga Provinces in South Africa [22-31]. B. maughamii is also categorized as declining in KwaZuluNatal Province [22], and research by Mander [32] ranked the species thirteenth out of 70 most widely demanded herbal medicine by consumers in the province. Similarly, Twine [33] ranked B. maughamii as third out of 36 tree species harvested for their bark in Southern Maputaland in KwaZulu-Natal Province, South Africa. Based on these reports, it is clear that $B$. maughamii has an enormous contribution to primary health care of local people in many areas of South Africa. Several people in developing countries depend on medicinal plants such as $B$. maughamii for their primary health care needs $[34,35]$. Therefore, this review is aimed at providing a comprehensive appraisal of the biological activities, phytochemistry, and medicinal uses of B. maughamii crude extracts.

\section{BOTANICAL DESCRIPTION OF B. MAUGHAMII}

B. maughamii is a medium-sized deciduous or semi-deciduous tree reaching $20-25 \mathrm{~m}$ in height $[17,19]$. B. maughamii has a spreading crown, branching at about $2 \mathrm{~m}$ above the ground level [14] with a straight, deeply folded, fluted, and buttressed trunk which is up to $30 \mathrm{~cm}$ or more in diameter [17]. The bark is smooth, yellowish brown, mottled, or gray in color and becoming roughly fissured in larger and older specimens $[14,18]$. The branches are usually yellow to grayishgreen in color, covered with short grayish-green hairs when young but becoming smooth with age, characterized by strong, robust, sharp conspicuous forked spines on the upper bole and branches as well as the younger stems. The leaves are compound made up of two leaflets on very short furry stalks, alternate and arranged spirally, with triangular stipules $[14,17,18]$. The leaflets are ovate to almost round in shape, acute or shortly acuminate, entire margins, dark gray-green in color, with velvet hairs when young and these persisting on the undersurface to maturity [18]. The flowers are small, inconspicuous, borne in small bunches, yellowish green in color, sessile or with short peduncle, petals with dense hairs on the outer surface $[14,18]$. The fruit is a oneseeded drupe, oblong-ellipsoid in shape, depressed at both ends and reddish brown in color at ripening [19]. The skin of the fruit is firm but thin, eventually brittle, containing spongy and fibrous, dark and oily mesocarp and a stone with thick endocarp [14,17-19]. 
B. maughamii is subdivided into two subspecies, subsp. maughamii and subsp. acuta Sands which are distinguished mainly by leaflet shape and pubescence. The leaflets on fertile shoots of subsp. maughamii are rounded or obtuse in shape and are pubescent, while those of subsp. acuta are acute to shortly acuminate and glabrous. The subsp. maughamii is widespread in distribution and has been recorded in Zimbabwe, Kenya, Mozambique, Malawi, South Africa, Zambia, and Swaziland [16-19,36-44]. The subsp. maughamii has been recorded in clay-loam, fine clay silt and sandy soil in sand forest, dry open woodland, bushland, seasonally waterlogged flood-plains, along river banks, near springs, around pans, dunes, sandstone outcrops, and termitaria at an altitude ranging from sea level to $1000 \mathrm{~m}$ above sea level [14,17-19,40]. The subsp. acuta has been recorded in Southeast Kenya and Northeast Tanzania in alkaline soil and light sandy soil on coral rag or lava in mixed coastal, lowland evergreen rainforest, ground-water forest, coastal thicket, and riverine thicker at an altitude ranging from sea level to $500 \mathrm{~m}$ above sea level [17]. However, most ethnobotanical and ethnopharmacological literature do not separate $B$. maughamii into specific subspecies, but rather B. maughamii sensu lato, and this is the approach that has been adopted in the current review.

The fruits of B. maughamii which have a pleasant sweet scent and taste, but later become bitter are edible in Southern Africa mainly as a snack [14,18,45-52]. According to Mahlo [53], the fruits of B. maughamii are used in South Africa as additives in the production of sweets and alcoholic beverages. The kernels of $B$. maughamii yield large quantities (about $60 \%$ ) of tasteless, odorless, clear and yellow edible oil that burns well and have good lubricative qualities and used as a massage oil $[14,19,38,45,48,54,55]$. Research by Grace and Sands [19] showed that oil pressed from the seed kernels of $B$. maughamii is used in the Limpopo Province in South Africa as a dressing for hides and skins. Since the oil from B. maughamii kernels is flammable, it is, therefore, suitable for industrial use [19].

\section{MEDICINAL USES OF B. MAUGHAMII}

The bark, fruits, leaves, and roots of $B$. maughamii are used for various traditional and medicinal applications (Table 1). B. maughamii is mainly used for magical purposes (good luck, wards off evil spirits, bath said to be stimulating, and exhilarating), as emetic, tonic, fish poison, insecticidal, and herbal medicine for bilharzia (Table 1 and Figure 1). Other minor medicinal applications recorded in a single country include use of the species as arrow poison, mosquito repellent, snail poison, purgative and panacea, and as herbal medicine for cough, malaria and nervous complaints [19-21,55-62]. In Mozambique, the bark of B. maughamii is mixed with Phaseolus vulgaris L. as an herbal medicine for hematuria [21]. In South Africa, the leaves of B. maughamii are used as ethnoveterinary medicine for diarrhea in cattle $[53,63,64]$.

\section{PHYTOCHEMICAL AND NUTRITIONAL COMPOSITION OF B. MAUGHAMII}

Very little attention has been paid to the macro- and micro-elements of B. maughamii. One report done by Dierenfeld et al. [78] partly studied this subject and reported values of the nutritional composition of leaves and twigs of B. maughamii (Table 2). Langlois [66] identified the compounds scopoletin and stigmasterol from the ethanol bark extract of B. maughamii while Olivier [55] identified alcohol precipitable solids and flavonoids from the bark extracts of the species (Table 3). The major aliphatic acids and aliphatic alcohols exceeding $10.0 \%$ identified from the fruits of B. maughamii include hexanal (14.0\%), isovaleric acid (15.7\%), and hexanoic acid (40.4\%) [79,80]. Major amino acids exceeding $10.0 \mathrm{mg} / \mathrm{g}$ of dry weight identified from the bark and leaves of B. maughamii include alanine, alloisoleucine, aspartic acid, tryptophan, glutamic acid, glycine, isoleucine, phenylalanine, lysine, proline, leucine, serine, histidine, threonine, glutamine, tyrosine, asparagine, and valine [55]. Future research should focus on evaluating the biological activities of the isolated compounds.

\section{BIOLOGICAL ACTIVITIES OF B. MAUGHAMII}

The following biological activities have been reported from the bark, fruit, leaf, and twig extracts of $B$. maughamii: Adulticidal $[60,81]$, antibacterial [53,82], antiplasmodial [67], bitterness [83], molluscicidal [84-86], and mutagenic [87,88] activities.

\section{Adulticidal activities}

Mavundza [60] and Mavundza et al. [81] evaluated the adulticidal activities of dichloromethane and ethanol bark extracts of $B$. maughamii against Anopheles arabiensis mosquitoes. Both dichloromethane and ethanol extracts exhibited activities with $55 \%$ and $65 \%$ mosquito mortality, respectively $[60,81]$.

\section{Antibacterial activities}

Mahlo [53] and Mahlo and Chauke [53,82] evaluated antibacterial activities of acetone leaf extracts of B. maughamii against Bacillus cereus, Pseudomonas aeruginosa, Escherichia coli, and Enterococcus faecalis using agar-dilution and serial dilution methods with tetracycline as a positive control. The minimum inhibitory concentration (MIC) values of extracts without polyethylene glycol (PEG) ranged from $0.2 \mathrm{mg} / \mathrm{ml}$ to $1.6 \mathrm{mg} / \mathrm{ml}$ while the addition of PEG resulted in a reduction of antibacterial activities with MIC values ranging from $3.1 \mathrm{mg} / \mathrm{ml}$ to $12.5 \mathrm{mg} / \mathrm{ml}[53,82]$.

Table 1: Medicinal applications of Balanites maughamii

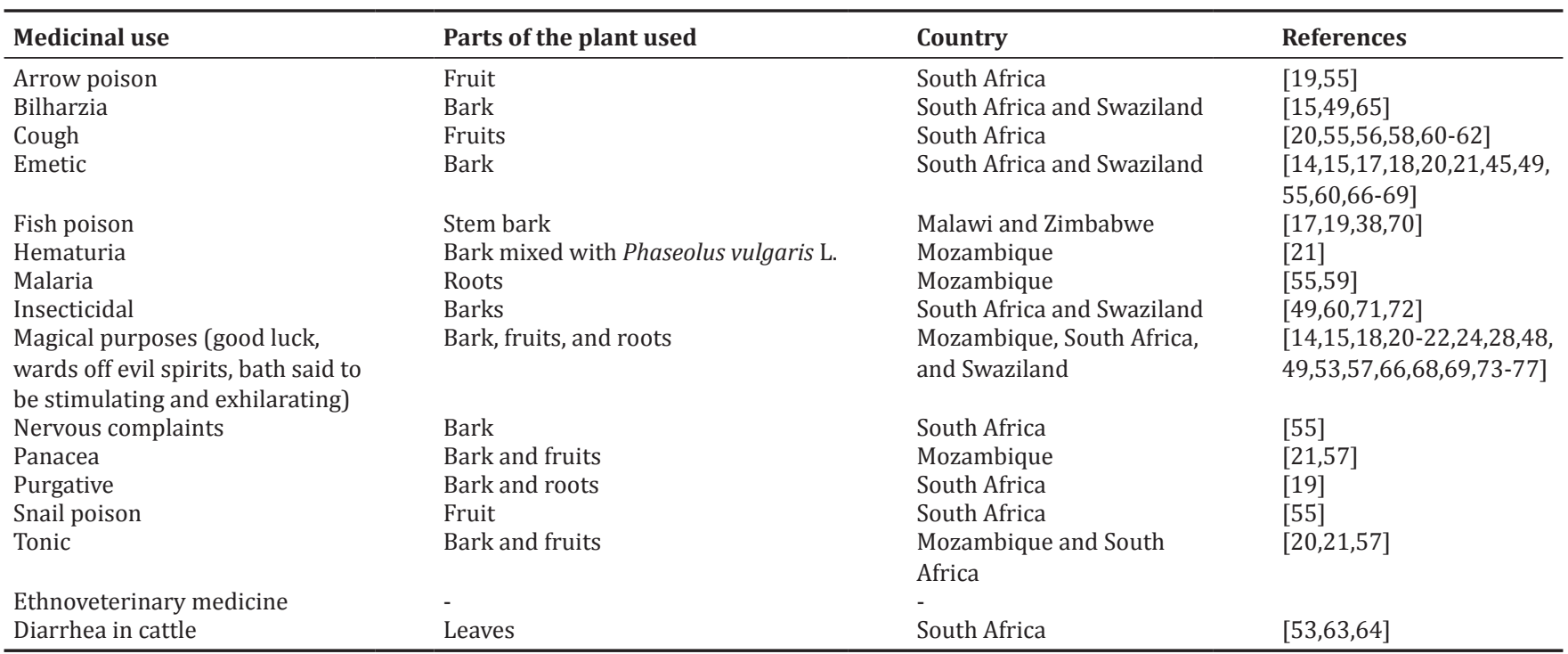




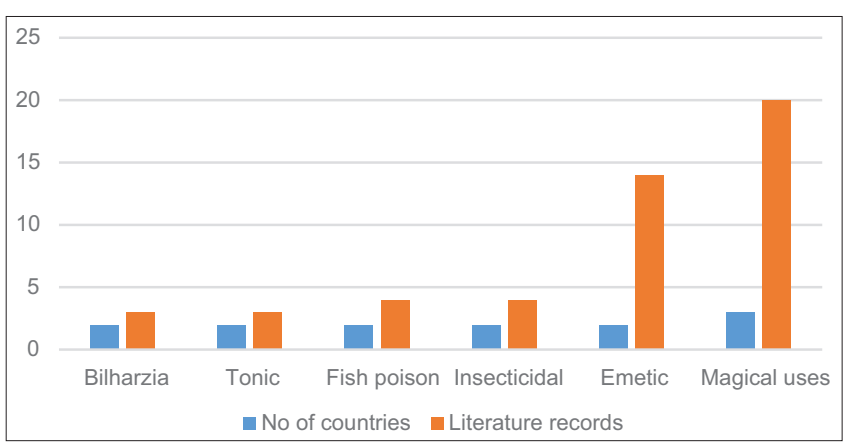

Fig. 1: Traditional and medicinal applications of Balanites maughamii

Table 2: Nutritional composition of Balanites maughamii leaves and twigs after Dierenfeld et al. [78]

\begin{tabular}{ll}
\hline Nutritional composition & Values \\
\hline Acid detergent bound protein (\% dry matter) & 1.9 \\
Acid detergent fiber (\% dry matter) & 40.4 \\
Ash (\% dry matter) & 7.4 \\
Calcium (\% dry matter) & 0.8 \\
Copper (\% dry matter) & 3.5 \\
Crude protein (\% dry matter) & 21.8 \\
Iron (\% dry matter) & 150.0 \\
Neutral detergent fiber (\% dry matter) & 64.5 \\
Magnesium (\% dry matter) & 0.4 \\
Manganese (\% dry matter) & 17.7 \\
Phosphorus (\% dry matter) & 0.2 \\
Potassium (\% dry matter) & 1.8 \\
Sodium (\% dry matter) & 0.03 \\
Sulfuric acid lignin (\% dry matter) & 13.9 \\
$\alpha$-tocopherols ( $\mu$ g/g dry matter) & 7.3 \\
-tocopherols ( $\mu$ g/g dry matter) & 8.0 \\
$\delta$-tocopherols ( $\mu$ g/g dry matter) & 3.0 \\
Vitamin E (IU/kg dry matter) & 11.8 \\
Water $(\%)$ & 68.1 \\
Zinc (\% dry matter) & 10.8 \\
\hline
\end{tabular}

\section{Antiplasmodial activities}

Prozesky et al. [67] evaluated the antiplasmodial activities of dichloromethane stem bark extracts of $B$. maughamii against Plasmodium falciparum by means of the flow cytometric test. The extract exhibited activities with half maximal inhibitory concentration value of $1.9 \mu \mathrm{g} / \mathrm{ml}$ [67].

\section{Bitterness activities}

Olivier and Van Wyk [83] evaluated the bitterness values of the bark of B. maughamii using procedures prescribed by the World Health Organization [89] and the European Pharmacopoeia [90] and compared the bitterness value of quinine hydrochloride set at 200000 . The bitterness value of $4211 \pm 2019$ was obtained for B. maughamii bark. The physiological effects associated with the bitter taste of herbal medicines are ascribed to the bitter tonic (amarum) effect, that is, result in the stimulation, secretion of saliva, secretion of gastric juices, and secretion of bile through taste stimuli through the nervus vagus [83].

\section{Molluscicidal activities}

Research by Wager [84] revealed that the fruits of B. maughamii that fell in infested water were observed to inhibit proliferation of snails and cercariae. Pretorius et al. [85] evaluated the molluscicidal properties of the kernel and pulp of ripe fruits of B. maughamii. The extracts were toxic to snails at concentrations of $25 \mathrm{mg} / \mathrm{ml}$, and molluscicidal activities were retained in powdered material for up to 122 days, but leaves and seeds showed no molluscicidal properties [85]. Ojewole [86] evaluated molluscicidal activities of the bark, fruit, and leaf extracts of B. maughamii by exposing adult Bulinus africanus and Biomphalaria pfeifferi to sublethal and lethal doses of crude and aqueous bark, leaf, and twig extracts of the species for a period of $24 \mathrm{~h}$ using niclosamide (Bayluscide $^{\circledR}$ ) (Coating Place Inc., Washington DC, WA, US) as reference molluscicide for comparison. The extracts demonstrated moderate to strong molluscicidal activity with lethal dose $90 \%$ value of $50 \mathrm{ppm}-100 \mathrm{ppm}$ compared to the positive control, niclosamide (Bayluscide ${ }^{\circledast}$ ) which killed all the snails at a dose of $1 \mathrm{ppm}$ [86].

\section{Mutagenic activities}

Elgorashi et al. [87] evaluated the mutagenic activities of dichloromethane and $90 \%$ methanol bark extracts of B. maughamii using the Ames test, micronucleus test, comet assay, and VITOTOX ${ }^{\circledR}$

Table 3: Phytochemical composition of Balanites maughamii

\begin{tabular}{llll}
\hline Phytochemical composition & Values & Parts & References \\
\hline Aliphatic acid & & & \\
Butanoic acid (\%) & 0.4 & Fruits & {$[79,80]$} \\
Heptanoic acid (\%) & 0.3 & Fruits & {$[79,80]$} \\
2-Heptenoic acid (\%) & 0.1 & Fruits & {$[79,80]$} \\
n-Hexadecanoic acid (\%) & 0.2 & Fruits & {$[79,80]$} \\
Hexanoic acid (\%) & 40.4 & Fruits & {$[79,80]$} \\
(E)-3-Hexenoic acid (\%) & 1.4 & Fruits & {$[79,80]$} \\
Isovaleric acid (\%) & 15.7 & Fruits & {$[79,80]$} \\
4-Methylpentanoic acid (\%) & 0.02 & Fruits & {$[79,80]$} \\
Nonanoic acid (\%) & 0.1 & Fruits & {$[79,80]$} \\
Octadecanoic acid (\%) & 0.02 & Fruits & {$[79,80]$} \\
(Z)-9-Octadecenoic acid (\%) & 0.01 & Fruits & {$[79,80]$} \\
Octanoic acid (\%) & 0.3 & Fruits & {$[79,80]$} \\
(Z)-2-Octenoic acid (\%) & 0.01 & Fruits & {$[79,80]$} \\
Pentadecanoic acid (\%) & 0.01 & Fruits & {$[79,80]$} \\
Tetradecanoic acid (\%) & Fruits & {$[79,80]$} \\
Valeric acid (\%) & 0.01 & Fruits & {$[79,80]$} \\
Aliphatic alcohol & 0.9 & & \\
Oct-1-en-3-ol (\%) & & Fruits & {$[79,80]$} \\
(E)-Oct-2-en-1-ol (\%) & 3.9 & Fruits & {$[79,80]$} \\
Octan-1-ol (\%) & 0.2 & Fruits & {$[79,80]$} \\
Aliphatic aldehyde & 2.0 & Fruits & {$[79,80]$} \\
(Z)-4-Decenal (\%) & & Fruits & {$[79,80]$} \\
Hexanal (\%) & 0.2 & Fruits & Fruits \\
Nonanal (\%) & 14.0 & & {$[79,80]$} \\
Octanal (\%) & 8.4 & 1.9 & \\
\hline
\end{tabular}


Table 3: (continued)

\begin{tabular}{|c|c|c|c|}
\hline Phytochemical composition & Values & Parts & References \\
\hline \multicolumn{4}{|l|}{ Aliphatic ester } \\
\hline Butyl hexanoate (\%) & 0.2 & Fruits & {$[79,80]$} \\
\hline n-Butyl hexadecanoate (\%) & 0.01 & Fruits & {$[79,80]$} \\
\hline Ethyl caproate (\%) & 2.3 & Fruits & {$[79,80]$} \\
\hline Methyl caproate (\%) & 3.0 & Fruits & {$[79,80]$} \\
\hline Propyl hexanoate (\%) & 0.05 & Fruits & {$[79,80]$} \\
\hline \multicolumn{4}{|l|}{ Aliphatic ketone } \\
\hline Nonan-2-one (\%) & 0.5 & Fruits & {$[79,80]$} \\
\hline Octan-3-one (\%) & 0.5 & Fruits & {$[79,80]$} \\
\hline$(E)$-3-Octen-2-one $(\%)$ & 1.0 & Fruits & {$[79,80]$} \\
\hline 3,4-Epoxy-2-octanone (\%) & 0.4 & Fruits & {$[79,80]$} \\
\hline \multicolumn{4}{|l|}{ Benzenoid compound } \\
\hline Methyl salicylate (\%) & 0.01 & Fruits & {$[79,80]$} \\
\hline \multicolumn{4}{|l|}{ Miscellaneous cyclic compounds } \\
\hline$\gamma$-n-Amylbutyrolactone(\%) & 0.02 & Fruits & {$[79,80]$} \\
\hline Bicyclo[3.3.1]nonane-2,7-dione (\%) & 0.05 & Fruits & {$[79,80]$} \\
\hline$\delta$-Caprolactone $(\%)$ & 0.6 & Fruits & {$[79,80]$} \\
\hline$\tau$-Caprolactone (\%) & 0.6 & Fruits & {$[79,80]$} \\
\hline Dimethylmaleic acid anhydride (\%) & 0.05 & Fruits & {$[79,80]$} \\
\hline Dimethyl trisulfide(\%) & 0.2 & Fruits & {$[79,80]$} \\
\hline$\gamma$-Ethoxy-butyrolactone(\%) & 0.04 & Fruits & {$[79,80]$} \\
\hline 5 -Ethyl-2 (5H)-furanone $(\%)$ & 0.03 & Fruits & {$[79,80]$} \\
\hline 1-(2-Methyl-1-cyclopenten-1-yl)-ethanone (\%) & 0.01 & Fruits & {$[79,80]$} \\
\hline S-Methyl methanethiosulfonate(\%) & 0.01 & Fruits & {$[79,80]$} \\
\hline \multicolumn{4}{|l|}{ Amino acid } \\
\hline Alanine (mg/g dry weight) & $40.6-158.0$ & Bark and leaves & [55] \\
\hline Alloisoleucine (mg/g dry weight) & $33.8-40.1$ & Bark and leaves & [55] \\
\hline$\alpha$-aminoadipic acid (mg/g dry weight) & $3.7-5.9$ & Bark and leaves & [55] \\
\hline$\alpha$-aminobutyric acid (mg/g dry weight) & $0.4-0.8$ & Bark and leaves & {$[55]$} \\
\hline Y-aminobutyric acid (mg/g dry weight) & $0.4-9.3$ & Bark and leaves & [55] \\
\hline$\beta$-aminoisobutyric acid (mg/g dry weight) & $4.1-5.0$ & Bark and leaves & [55] \\
\hline Asparagine (mg/g dry weight) & 38.1 & Bark and leaves & [55] \\
\hline Aspartic acid (mg/g dry weight) & $56.7-308.1$ & Bark and leaves & [55] \\
\hline Cysteine (mg/g dry weight) & 9.4 & Bark and leaves & [55] \\
\hline Glutamic acid (mg/g dry weight) & $61.4-84.4$ & Bark and leaves & [55] \\
\hline Glutamine (mg/g dry weight) & 18.5 & Bark and leaves & {$[55]$} \\
\hline Glycine (mg/g dry weight) & $2.7-10.0$ & Bark and leaves & [55] \\
\hline Histidine (mg/g dry weight) & 12.5 & Bark and leaves & [55] \\
\hline Isoleucine (mg/g dry weight) & $22.4-33.5$ & Bark and leaves & [55] \\
\hline Leucine (mg/g dry weight) & 29.2 & Bark and leaves & [55] \\
\hline Lysine (mg/g dry weight) & $11.5-21.1$ & Bark and leaves & [55] \\
\hline Methionine (mg/g dry weight) & $2.6-3.0$ & Bark and leaves & [55] \\
\hline Ornithine (mg/g dry weight) & 9.7 & Bark and leaves & [55] \\
\hline Phenylalanine (mg/g dry weight) & $18.0-32.2$ & Bark and leaves & [55] \\
\hline Proline (mg/g dry weight) & $32.6-99.1$ & Bark and leaves & [55] \\
\hline Serine (mg/g dry weight) & $13.1-26.7$ & Bark and leaves & {$[55]$} \\
\hline Threonine (mg/g dry weight) & 12.9 & Bark and leaves & [55] \\
\hline Tryptophan (mg/g dry weight) & $12.3-14.2$ & Bark and leaves & [55] \\
\hline Tyrosine (mg/g dry weight) & $15.7-29.3$ & Bark and leaves & [55] \\
\hline Valine (mg/g dry weight) & $32.9-51.7$ & Bark and leaves & [55] \\
\hline
\end{tabular}

test. All the extracts showed mutagenicity or DNA damage and chromosomal aberrations in at least one test [87]. Similarly, Taylor et al., [88] evaluated the genotoxic activities of dichloromethane and $90 \%$ methanol leaf extracts of B. maughamii in human peripheral blood lymphocytes using the micronucleus test. The leaf extract showed positive results in all micronucleus tests, while the twig extract was positive in micronucleus and Comet tests without S9 (human white blood cells in vitro) [88].

\section{CONCLUSION}

The present review summarizes the ethnomedicinal uses, phytochemistry and biological activities of the bark, fruit, leaf, and twig extracts of B. maughamii. In the past 80 years, $B$. maughamii has been the subject of pharmacological research, focusing on the molluscicidal activities of the species. Early research revealed that the fruits of B. maughamii are lethal to freshwater snails and other organisms that transmit the parasitic dimorphic Schistosoma trematode worms which cause schistosomiasis also known as bilharzia. From a chemical, pharmacological and toxicological point of view, B. maughamii has not received any major emphasis. At present, there is not yet enough data on ethnopharmacological evaluations on the species that can be correlated with its medicinal applications. Therefore, detailed phytochemical, pharmacological, and toxicological studies of B. maughamii are recommended.

\section{ACKNOWLEDGMENTS}

I would like to express my gratitude to the National Research Foundation, South Africa, and Govan Mbeki Research and Development Centre, University of Fort Hare for financial support to conduct this study.

\section{AUTHOR'S CONTRIBUTIONS}

The author declares that this work was done by the author named in this article. 


\section{CONFLICTS OF INTEREST}

The author declares that they have no conflicts of interest.

\section{REFERENCES}

1. Sheahan MC. Zygophyllaceae. In: Kubitzki K, editor. The Families and Genera of Vascular Plants: Flowering Plants Eudicots. Berlin: Springer; 2007. p. 488-500.

2. Hutchinson J. The Families of Flowering Plants. Oxford: Clarendon Press; 1973.

3. Sands MJ. Balanitaceae. In: Hedberg I, Edwards S, editors. Flora of Ethiopia 3. Addis Ababa: Addis Ababa University; 1989. p. 433-6.

4. Figueiredo E, Smith GF. Plants of Angola. Strelitzia 22. Pretoria: South African National Biodiversity Institute; 2008.

5. Cronquist A. An Integrated System of Classification of Flowering Plants. New York: Columbia University Press; 1981.

6. Fahn A, Werker E, Baas P. Wood Anatomy and Identification of Trees and Shrubs from Israel and Adjacent Regions. Jerusalem: Israel Academy of Science and Humanities; 1986.

7. Narayana L, Satyanarayana P, Radhakrishnaiah H. Systematic position of Balanitaceae. In: Bilgrami K, Dogra J, editors. Phytochemistry and Plant Anatomy. Dehli: CBS Publications; 1990. p. 157-64.

8. Sheahan MC, Chase MW. A phylogenetic analysis of Zygophyllaceae R.Br. based on morphological, anatomical and rbcL DNA sequence data. Bot J Linn Soc 1996;122:279-300.

9. Sheahan MC, Chase MW. Phylogenetic relationships within Zygophyllaceae based on DNA sequences of three plastid regions, with special emphasis on zygophylloideae. Syst Bot 2000;25:371-84.

10. Savolainen V, Fay MF, Albach DC, Backlund A, Van der Bank M, Cameron KM, et al. Phylogeny of the Eudicots: Anearly complete familial analysis based on rbcL gene sequences. Kew Bull 2000;55:257-309.

11. Beier BA, Chase MW, Thulin M. Phylogenetic relationships and taxonomy of subfamily zygophylloideae (Zygophyllaceae) based on molecular and morphological data. Plant Syst Evol 2003;240:11-39.

12. Jackson WP. Origins and Meanings of Names of South African Plant Genera. Cape Town: University of Cape Town; 1990.

13. Behr K. Balanites maughamii sub sp. maughamii; 2006. Available from: http://www.pza.sanbi.org/balanites-maughamii-subsp-maughamii. [Last accessed on 2019 Mar 19]

14. Palmer E, Pitman P. Trees for Southern Africa Covering all Known Indigenous Species in Republic of South Africa, South West Africa, Botswana, Lesotho and Swaziland. Cape Town: A.A. Balkema; 1972.

15. Schmidt E, Lotter M, McCleland W. Trees and Shrubs of Mpumalanga and Kruger National Park. Johannesburg: Jacana Media; 2002.

16. Hyde MA, Wursten BT, Ballings P, Palgrave MC. Balanites manghamii Sprague; 2019. Available from: https://www. zimbabweflora.co.zw/speciesdata/species.php?species_id=132970. [Last accessed on 2019 Mar 19].

17. Sands MJ. The desert date and its relatives: A revision of the genus Balanites. Kew Bull 2001;56:1-128.

18. Palgrave MC. Keith Coates Palgrave Trees of Southern Africa. Cape Town: Struik Publishers; 2002.

19. Grace OM, Sands MJS. Balanites maughamii sprague. In: Van der Vossen HA, Mkamilo GS, editors. Vegetable Oils: Plant Resources of Tropical Africa 14. Wageningen: Backhuys Publishers; 2007. p. 40-2.

20. Van Wyk BE, Van Oudtshoorn B, Gericke N. Medicinal plants of South Africa. Pretoria: Briza Publications; 2013.

21. Van Wyk BE, Gericke N. People's Plants: A Guide to Useful Plants of Southern Africa. Pretoria: Briza Publications; 2007.

22. Cunningham AB. An Investigation of the Herbal Medicine Trade in Natal/KwaZulu. Pietermaritzburg: Investigational Report No. 29, Institute of Natural Resources; 1988.

23. Cunningham AB. African Medicinal Plants: Setting Priorities at the Interface between Conservation and Primary Health Care. Paris: People and Plants Working Paper 1, UNESCO; 1993

24. Netshiluvhi TR. Aspects of Seed Propagations of Commonly Utilised Medicinal Trees of KwaZulu-Natal. MSc Dissertation. Pietermaritzburg: University of Natal; 1996.

25. Botha J, Witkowski ET, Shackleton CM. An inventory of medicinal plants traded on the western boundary of the kruger national park, South Africa. Koedoe 2001;44:7-46.

26. Williams VL, Balkwill K, Witkowski ET. Unravelling the commercial market for medicinal plants and plant parts on the witwatersrand, South Africa. Econ Bot 2000;54:310-27.

27. Williams VL, Balkwill K, Witkowski ET. A lexicon of plants traded in the witwatersrand umuthi shops, South Africa. Bothalia 2001;31:71-98.
28. Grace OM, Prendergast HD, Jäger AK, van Staden J. Bark medicines used in traditional healthcare in KwaZulu-Natal, South Africa: An inventory. S Afr J Bot 2003;69:301-63.

29. Williams VL. Hawkers of Health: An Investigation of the Faraday Street Traditional Medicine Market in Johannesburg, Gauteng. Johannesburg: Plant Ecology and Conservation Series No. 15, Report Gauteng Directorate for Nature Conservation, DACEL; 2003.

30. Williams VL, Witkowski ET, Balkwill K. Volume and financial value of species traded in the medicinal plant markets of Gauteng, South Africa. Int J Sustain Dev World Ecol 2007; 14:584-603.

31. Williams VL, Victor JE, Crouch NR. Red Listed medicinal plants of South Africa: Status, trends, and assessment challenges. S Afr J Bot 2013;86:23-35.

32. Mander M. Marketing of Indigenous Medicinal Plants in South Africa: A Case Study in KwaZulu-Natal. Rome: Food and Agriculture Organization of the United Nations; 1998.

33. Twine W. Medicinal bark harvesting and yields in woodlands: A case study from southern Maputaland. In: Lawes MJ, Eeley HA, Shackleton CM, Geach BG, editors. Indigenous Forests and Woodlands in South Africa: Policy, People and practice. Pietermaritzburg: University of Natal Press; 2004. p. 533-7.

34. Maroyi A. Phytochemical and ethnopharmacological review of Heteropyxis natalensis. Asian J Pharm Clin Res 2019;12:8-15.

35. Maroyi A. Lannea schimperi: Review of its botany, medicinal uses, phytochemistry and biological activities. Asian J Pharm Clin Res 2019;12:31-6.

36. Launert E. Balanitaceae. In: Exell AW, Fernandes A, Wild H, editors. Flora Zambesiaca. Vol. 2. London: Crown Agents for Oversea Governments and Administrations; 1963. p. 221-4.

37. Drummond RB. A list of trees, shrubs and woody climbers indigenous or naturalised in Rhodesia. Kirkia 1975;10:229-85.

38. Van Wyk B, van Wyk P. Field Guide to Trees of Southern Africa. Cape Town: Struik Publications (Pty) Ltd; 1997.

39. Von Breitenbach J, De Winter B, Poynton R, Van der Berg E, Van Wyk AE, Van Wyk E. Pocket List of Southern African Indigenous Trees Including Selected Shrubs and Woody Climbers. Pretoria: Briza Publications; 2001

40. Germishuizen G, Meyer NL. Plants of Southern Africa: An Annotated Checklist. Strelitzia 14. Pretoria: National Botanical Institute; 2003.

41. Sands MJ. Balanitaceae. In: Beentje HJ, Ghazanfar SA, editors. Flora of Tropical East Africa. Lisse: A.A. Balkema; 2003. p. 1-16.

42. Da Silva MC, Izidine S, Amuda AB. A Preliminary Checklist of the Vascular Plants of Mozambique. SABONET Report No. 30. Pretoria: South African National Biodiversity Institute; 2004

43. Mapaura A, Timberlake J. A Checklist of Zimbabwean Vascular Plants. SABONET Report No. 33. Pretoria: South African National Biodiversity Institute; 2004.

44. Burrows JE, Burrows SM, Lötter MC, Schmidt E. Trees and Shrubs Mozambique. Cape Town: Publishing Print Matters (Pty); 2018.

45. Watt JM, Breyer-Brandwijk MG. The Medicinal and Poisonous Plants of Southern and Eastern Africa. London: E. and S. Livingstone; 1962.

46. Fox FW, Young ME. Food from the Veld. Johannesburg: Delta Books; 1982.

47. Ackhurst AA. Interactive Database on all Edible Fruits in Southern Africa. MSc Dissertation. Johannesburg: Rand Afrikaans University; 1996.

48. Hutchings A, Scott AH, Lewis G, Cunningham AB. Zulu Medicinal Plants: An Inventory. Pietermaritzburg: University of Natal Press; 1996.

49. Long C. Swaziland's Flora: SiSwati Names and Uses. Swaziland National Trust Commission, Mbambane; 2005. Available from: http:// www.sntc.org.sz/index.asp. [Last accessed on 2019 Apr 04].

50. Shava S. Research on indigenous knowledge and its application: A case of wild food plants of Zimbabwe. South Afr J Environ Educ 2005;22:73-86.

51. Magwede K, Van Wyk BE, Van Wyk AE. An inventory of vhavenda useful plants. S Afr J Bot 2018. DOI: 10.1016/J.Sajb.2017.12.013.

52. Welcome AK, Van Wyk BE. An inventory and analysis of the food plants of Southern Africa. S Afr J Bot 2018. DOI: 10.1016/J. SAJB.2018.11.003

53. Mahlo MS. Antibacterial Activity of Selected Plants Used in Ethnoveterinary Medicine. MSc Dissertation. Sovenga: University of Limpopo; 2006.

54. Peters CR, O'Brien EM, Drummond RB. Edible Wild Plants of Subsaharan Africa. London: Royal Botanic Gardens, Kew; 1992.

55. Olivier DK. The Ethnobotany and Chemistry of South African Tonic Plants. PhD Thesis. Johannesburg: University of Johannesbur; 2012.

56. Iwu MM. Empirical investigations of dietary plants used in igbo 
ethnomedicine. In: Etkin NL, editor. Plants in Indigenous Medicine and Diet: Behavioural Approaches. New York: Redgrave Publishing Co.; 1986. p. 131-56.

57. Izidine SA. Licuáti Forest Reserve, Mozambique: Flora, Utilization and Conservation. MSc Dissertation. Pretoria: University of Pretoria; 2003.

58. McGaw LJ, Lall N, Meyer JJ, Eloff JN. The potential of South African plants against Mycobacterium infections. J Ethnopharmacol 2008; 119:482-500

59. Ribeiro A, Romeiras MM, Tavares J, Faria MT. Ethnobotanical survey in canhane village, district of massingir, Mozambique: Medicinal plants and traditional knowledge. J Ethnobiol Ethnomed 2010;6:33.

60. Mavundza EJ. Mosquitocidal activity Against Anopheles arabiensis of Plants used as Mosquito Repellents in South Africa. PhD Thesis. Pietermaritzburg: University of KwaZulu-Natal; 2014.

61. Chingwaru W, Vidmar J, Kapewangolo PT. The potential of subsaharan African plants in the management of human immunodeficiency virus infections: A review. Phytother Res 2015;29:1452-87.

62. Khan AU, Gilani AH. Natural products useful in respiratory disorders: Focus on side-effect neutralizing combinations. Phytother Res 2015;29:1265-85.

63. Luseba D, Van der Merwe D. Ethnoveterinary medicine practices among Tsonga speaking people of South Africa. Onderstepoort J Vet Res 2006;73:115-22.

64. McGaw LJ, Eloff JN. Ethnoveterinary use of Southern African plants and scientific evaluation of their medicinal properties. J Ethnopharmacol 2008;119:559-74.

65. Clark TE, Appleton CC, Drewes SE. A semi-quantitative approach to the selection of appropriate candidate plant molluscicides a South African application. J Ethnopharmacol 1997;56:1-3.

66. Langlois A. The Chemical Investigation of four Medicinal Plants. MSc Dissertation. Durban: University of Natal; 2000.

67. Prozesky EA, Meyer JJ, Louw AI. In vitro antiplasmodial activity and cytotoxicity of ethnobotanically selected South African plants. J Ethnopharmacol 2001;76:239-45.

68. Sobiecki JF. A preliminary inventory of plants used for psychoactive purposes in Southern African healing traditions. Trans Royal Soc S Afr 2002;57:1-24

69. Aston Philander L. An ethnobotany of Western cape rasta bush medicine. J Ethnopharmacol 2011;138:578-94.

70. Neuwinger HD. Plants used for poison fishing in tropical Africa. Toxicon 2004;44:417-30

71. Mavundza EJ, Maharaj R, Finnie JF, Kabera G, Van Staden J. An ethnobotanical survey of mosquito repellent plants in uMkhanyakude district, KwaZulu-Natal province, South Africa. J Ethnopharmacol 2011;137:1516-20.

72. Pavela R, Benelli G. Ethnobotanical knowledge on botanical repellents employed in the African region against mosquito vectors a review. Exp
Parasitol 2016;167:103-8.

73. Dlamini B. Swaziland Flora: Their Local Names and Uses. Mbabane: Ministry of Agriculture and Cooperatives, Forestry Section; 1981

74. Liengme CA. Plants used by the Tsonga people of Gazankulu. Bothalia 1981;13:501-18

75. Mabogo DE. The Ethnobotany of the Vhavenda. MSc Dissertation. Pretoria: University of Pretoria; 1990.

76. Pooley E. The Complete Field Guide to Trees of Natal, Zululand and Transkei. Durban: Natal Flora Publications Trust; 1998.

77. Corrigan BM, Van Wyk BE, Geldenhuys CJ, Jardine JM. Ethnobotanical plant uses in the KwaNibela Peninsula, St Lucia, South Africa. S Afr J Bot 2011;77:346-59.

78. Dierenfeld ES, du Toit R, Braselto WE. Nutrient composition of selected browses consumed by black rhinoceros (Diceros bicornis) in the Zambezi valley, Zimbabwe. J Zoo Wildl Med 1995;26:220-30.

79. Viljoen S. Elephant Fruit: The Dispersal Attributes of Balanites maughamii. MSc Dissertation. Cape Town: University of Cape Town; 2013

80. Midgley JJ, Kruger LM, Viljoen S, Bijl A. Fruit and seed traits of the elephant-dispersed African savanna plant Balanites maughamii. J Trop Ecol 2015;31:557-61.

81. Mavundza EJ, Maharaj R, Chukwujekwu JC, Finnie JF, Van Staden J. Screening for adulticidal activity against Anopheles arabiensis in ten plants used as mosquito repellent in South Africa. Malar J 2014;13:173.

82. Mahlo SM, Chauke H. Antibacterial activity of selected medicinal plants used in ethnoveterinary medicine. J Med Plant Res 2013;7:2777-82.

83. Olivier DK, van Wyk BE. Bitterness values for traditional tonic plants of Southern Africa. J Ethnopharmacol 2013;147:676-9.

84. Wager VA. The possibility of eradicating bilharzia by extensive planting of the tree Balanites. S Afr Med J 1936;10:10-1.

85. Pretorius SJ, Joubert PH, Evans AC. A re-evaluation of the molluscicidal properties of the torchwood tree, Balanites maughamii sprague. S Afr J Sci 1988;84:201-2.

86. Ojewole OJ. Indigenous plants and schistosomiasis control in South Africa: molluscicidal activity of some zulu medicinal plants. Bol Latinoam Caribe Plant Med Aromáticas 2004;3:8-22.

87. Elgorashi EE, Taylor JL, Maes A, De Kimpe N, Van Staden J, Verschaeve L. The use of plants in traditional medicine: Potential genotoxic risks. S Afr J Bot 2002;68:408-10.

88. Taylor JL, Elgorashi EE, Maes A, Van Gorp U, De Kimpe N, Van Staden J, et al. Investigating the safety of plants used in South African traditional medicine: Testing for genotoxicity in the micronucleus and alkaline comet assays. Environ Mol Mutagen 2003;42:144-54

89. World Health Organisation (WHO) Quality Control Methods for Medicinal Plant Materials. Geneva: World Health Organisation; 2002.

90. European Pharmacopoeia. Bitterness Value. Strasbourg: Council of Europe; 2005 